\title{
School Physical Education courses: A study on challenges and on restoring their functions
}

\author{
Mustafa Toprak $^{1 *}$, Yunus Emre Avci ${ }^{2}$, Ömer Cengiz ${ }^{3}$ \\ ${ }^{1}$ Assistant Professor, The American University in Cairo, New Cairo, Egypt \\ ${ }^{2}$ Assistant Professor, Siirt University, Siirt, Turkey \\ ${ }^{3}$ Assistant Professor, Siirt University, Siirt, Turkey
}

\begin{abstract}
This study represents an effort to explore and understand the experiences of individuals who have significant stakes on Physical Education and Sports (PES) courses either through being practically involved in teaching or planning this course or by being theoretically engaged in discourses relevant to the nature and normative enactment of the course. The main purpose of this study is to explore the status of Physical Education course through unveiling the voices of significant stakeholders. To this end, this qualitative study relied on several parameters: an examination of curriculum of physical education, Ministry of Education's (MoNE's) efforts and initiative to increase success at sports, the role of sports clubs at school along with an exploration of key 29 stakeholders' experiences through semi-structured interviews. The results gathered through content analysis highlight that physical education and sports courses are mostly perceived of little worth, and that development of a strong sport culture is largely hindered by financial, systemic, and administrative constraints. The study also points out the urgent call for introduction of system-wide regulations and policies and further fortification of facilities.
\end{abstract}

Keywords: Physical education course, multiple-stakeholder perspective, teach-to-the-test, sports education policy, qualitative study

\section{INTRODUCTION}

Physical and social environment combined with an interaction of behavior and biology are among the salient determiners of an individual's health and school provides both a physical and social environment for a student (U.S. Department of Health and Human Services, 2010). Physical education (PE) course is designed to provide such a rich environment where students' awareness towards well-being and exercise is bolstered on a continuous basis. If appropriately designed and implemented, these courses can serve a range of purposes. They can grant students access to health-improving physical activities through movement education that aims at fostering motor skills competence, sports education by guiding students to become skillful players in lifetime sports of their choosing, and fitness education that introduces the benefits and scientific principles of exercise, which could assist in effectively managing and sustaining lifestyle changes (Kohl III \& Cook, 2013).

Sallis et al. (2012) also mention the benefits of physical activity at schools. They identify PE course as HOPE (Health Optimizing Physical Education) and accentuate its role in developing knowledge, skills, abilities, and confidence for being physically active and for fighting obesity epidemic. However, these potential benefits seem to be dwarfed by various factors that are internal and external to schools including but not limited to the lack of and limited access to facilities, crowded curriculum, low subject status, teachers' lack of training, limited curriculum time allocations, inadequacy of appropriately qualified $\mathrm{PE}$ teachers, relevance and quality of the PE curriculum (Hardman, 2008; McKenzie \& Lounsbery, 2009; Kohl III \& Cook, 2013). Researchers such as Chomitz et al. 2009; Kohl III \& Cook, 2013 show that school children's academic performance, mathematics and reading performance in particular, is negatively influenced by a lack of physical activity and that physical fitness may improve academic performance. Physical activity has also been shown elsewhere (Morrow Martin, Welk, Zhu, \& Meredith, 2010) to be instrumental in mitigating violent and antisocial incidents. Despite the reported roles physical activity plays in schooling, lack of such activity at schools (Tercedor et al., 2017) could lead to serious issues such as restlesness, antisocial behavior, low academic performance and obesity, to name a few. Inevitably, school environments that are not well-designed for physical activity and that do not well encourage and ensure physical activity put students at many social-emotional and cognitive risks. Despite the immense benefits it can offer both to the individual and the society, this course, intentionally or

Corresponding Author e-mail: mustafa.toprak@aucegypt. edu

https://orcid.org/0000-0002-9390-3481

How to cite this article: Toprak M, AvcI YE, Cengiz O, (2021). School Physical Education courses: A study on challenges and on restoring their functions. Pegem Journal of Education and Instruction, Vol. 11, No. 4, 2021, 306-315

Source of support: Nil

Conflict of interest: None.

DOI: 10.47750/pegegog.11.04.29

Received: 23.03.2021

Accepted: 28.07.2021 Publication: 01.10.2021 
not, seems to have been belittled and discredited (Osborne, Belmont, Peixoto, Azevedo, \& Carvalho, 2016) by many school members. This inattention appears to continue despite its inclusion in the curriculum and class schedules. Further, such negligence has become so much ingrained in many schools' culture that it is hardly questioned and it is treated as 'the elephant in the room'.

The current research landscape on PE course seems fragmented. Much research focuses on development of young athletes from stakeholders' points of view (Kristiansen \& Houlihan, 2017), on how a meaningful PE should look like (Beni, Chróinín, \& Fletcher, 2018), on policy problems and solutions (Penney, 2017; Stylianou, Hogan \& Enright, 2019), on new reforms in PE (Lund, 2014), and on sports coaches (Smith, 2015). Despite a quantitative analysis of the situation of physical education (Hardman, 2008), there has been little qualitative exploration with the goal of mapping out a general outlook of issues surrounding PE education. Also, while much research focuses on PE courses at higher education and teacher education programs (Hayes, Capel, Katene, \& Cook, 2008; Kim, Cardinal, \& Cardinal, 2015; Engstrom, 1999), there remains a paucity of evidence on K-12 PE courses. Studies on attitudes towards PE courses are focused on teachers' perspectives (Bozoglu \& Göktürk, 2016; Gordon, Dyson, Cowan, McKenzie, \& Shulruf, 2016; Marinsek \& Kovac, 2019; Simmons \& MacLean, 2018), students' perspective (Mercier, Donovan, Gibbone, \& Rozga, 2017; Mohammed \& Mohammad, 2012; Phillips \& Silverman, 2015), administrators' perspective (Oh \& Graber, 2019; Zeng \& Wang, 2015) or parents' (Nisskaya, 2018). However, there has been no study to date that presents an in-depth comprehensive exploration of PE courses at K-12 level through a consolidation of perspectives of various stakeholders (teachers, academics, athletes, coaches). This study, therefore, intends to develop an understanding of PE education by unveiling voices of significant stakeholders. To achieve this aim, it seeks to address the following two key research questions:

- How is the Physical Education and Sports Culture is situated in policy and in practice?

- What recommendations are proposed to improve Physical Education and Sports Culture course at schools?

The study is significant in terms of its contribution to furthering our understanding of implementation of $\mathrm{PE}$ courses at school level, in pinpointing the existing barriers and dysfunctions and, in providing insights that can guide future action at policy and practice levels. PE course in K-12 education: Policy, norms, and issues

McKenzie and Lounsbery (2008) refers to PE courses as "the pill not taken", meaning that it runs short of achieving an important goal: providing students of promising physical activity. Through PE courses, schools undertake another responsibility: providing physical activity opportunities to students. Haible et al. (2019) affirm that this role is expanded to include "the enhancement of students' knowledge, understanding, skills, and motivation to enjoy a (healthy) physically active lifestyle throughout the lifespan" (p.2). Additionally, PE courses are viewed as instrumental in building a culture of physical activity that extend to later life in the form of sports routines (Hardman, 2008).

The fact that students spend most of their time at schools and the research evidence that physical activity and learning are interrelated creates an imperative for schools to promote physical activity (Kohl III \& Cook, 2013). Research evidence such as those by Haible et al. (2019) reaffirms the role of PE courses on promoting physical activity related health competence in cognitive, physical and motivational domains. This consensus on PE course's description of being the "optimal setting to increase the physical activity opportunities during the school day" (Kirkham-King, et al., 2017, p.132) and its instrumentality is shared by around $95 \%$ of countries that enact it as a compulsory course at schools (Hardman, 2008). Additionally, PE is generally well received and perceived by students. A study conducted by Çelik, Koçkaya and Parlar (2018) with 402 students revealed that most students have quite positive attitudes towards this class. Sağın and Karabulut (2019) also found out that the level of value students place on various dimension of PE course are high. What is more, although comparably at lower levels, teacher candidates (Demir, Cicioğlu, İlhan, \& Arslan, 2017), teachers (Pehlivan, Dönmez \& Yaşat (2005), and school administrators (Tutal, 2014) also rate it as a valuable course. However, issues abound when it comes to the enactment of PE at schools. Demirhan, Bulca, Saçlı and Kangalgil (2018), for instance, highlighted various issues: administrators place relatively low level of importance to PE course, parents lack awareness, students do not attend the class with appropriate attire, schools lack equipment and facilities, there is a need for more PE sessions, girls have low levels of interest, and high class-density interrupts with good planning. Lack of equipment and facilities are cited as other barriers by Pehlivan, Dönmez and Yaşat (2005).

Mamak (2012) who collected data from 239 PE teachers echoed the researchers above. He found out that around 80 $\%$ of teachers believe that students have not fully grasped the importance of PE course, more than $80 \%$ of the participant teachers blamed crowded classes and lack of equipment and facilities as barriers while around $75 \%$ mention that the number of PE class sessions are not sufficient.

By and large, the literature appears to highlight two main lines. First, PE as a course is liked by various internal stakeholders (students, teachers, administrators). How stakeholders view the assumed role and function of $\mathrm{PE}$ as mandated in policy documents and curriculum, how practitioners implement these intentions in the documents and spelled out by people highlight the complex nature of 
the course (Stylianou, Hogan \& Enright, 2019). Likewise, the positioning of PE as a soft policy that "comes in the form of recommendations, education campaigns and strong advocacy" (Kennedy, Chan, \& Fok, 2011, p.44) adds to this complexity and it further problematized PE courses at schools. Second, functions of PE are hindered by various factors particularly by the lack of equipment and facilities and by the overcrowded classes.

\section{PE course in Turkey}

Although PE is titled Physical Education and Games in Turkish primary schools and as Physical Education and Sports in Turkish secondary schools, both aim to develop this set of skills: resilience, quickness, flexibility, mobility, coordination, strength and rhythm (Ministry of National Education, 2018a; Ministry of National Education, 2018b). It is offered five times a week until $4^{\text {th }}$ grade and starting with $4^{\text {th }}$ grade it is offered twice a week to secondary $\left(5^{\text {th }}, 6^{\text {th }}, 7^{\text {th }}\right.$ and $8^{\text {th }}$ graders $)$ and high school students $\left(9^{\text {th }}, 10^{\text {th }}, 11^{\text {th }}\right.$ and $12^{\text {th }}$ graders (Talim Terbiye Kurulu Başkanlığ 1,2018$)$. There is also an elective course titled Sports and Physical Activities available to secondary school students twice a week in addition to Physical Educations Sports offered to high school students as an elective twice a week.

\section{Theoretical Framework}

This study adopts Schlecty's (2015) school culture framework that consists of the triad of preachment, practice, pretests. The framework draws a distinction between what is preached and what is put into practice and posits that pretests, the deeply held assumptions, have a determining impact on the gulf between these two concepts. In other words, at schools, education systems and its subsystems, official documents particularly policy documents include narratives based on best practices and ideals on education (preachments) and individuals tend to preach these practices and ideals when asked. However, a stark mismatch can be observed when these ideals are practiced in real life. A most potent explanation for this mismatch is the assumptions and beliefs held by individuals as these assumptions and beliefs, not the narratives, are the underlying systems that influence the practice. This framework is deemed best fit as a theoretical lens to interpret the data in this study because approaches towards PE course are quite positive and supportive both in written and spoken versions of the narrative but practices are not quite aligned with this narrative.

\section{Method}

\section{Research Design}

This study adopts a qualitative research methodology that seeks to take note of "the individual perspectives of the participants' and thus 'giving voice to those perspectives" (Lodico, Spaulding, \& Voegtle, 2010, p.16) with the goal of understanding key stakeholders' perspectives on physical education and sports course.

\section{Study Group}

Because our aim was to gather views of multiple stakeholders of academics, coaches, teachers, athletes, we have used the maximum variation sampling, one of the purposive sampling methods, to select participants. To increase variability and to collect rich data, criterion (experience on physical education) sampling strategy was also employed to recruit relevant participants. Through this strategy, 5 academicians, 8 coaches, 11 physical education and sports teachers, 5 national athletes, a total of 29 people voluntarily participated in the study. Participants signed an informed consent form through which they were ensured about confidentiality of their information and were informed about their right to withdraw from the study.

\section{Data Collection}

Semi-structured interviews that were held at school premises were used as primary tools to collect data in this study while researchers also relied on the notes they took during the interviews. A semi-structured interview protocol that included nine open-ended questions was developed by the researchers after a review of the relevant literature. Purpose of the research and research questions were also considered when the protocol was developed. Some sample questions are: 'do you think that the physical education and sports culture subject in the national education program is sufficient for the formation of sports culture? Why?' and 'The Ministry of National Education is preparing to accept sportive achievement as criteria in national exams such as Temel Eğitimden Ortaöğretime Geçiş Sistemi (Transition from Basic Education to Secondary Exam), Yüksek Öğretime Geçiş Sınavı (Transition to Higher Education Exam). How do you view this situation? Would this contribute to the education system?'.

\section{Data Analysis}

Each participant was coded with a letter and number (e.g., $\mathrm{Ac}=$ academic, $\mathrm{C}=$ coach, $\mathrm{T}=$ teacher, Ath= Athlete) to ensure confidentiality. Table 1 shows further demographic information of the participants. Data was analyzed following the steps suggested by Miles and Huberman (1994) and Plano-Clark and Creswell (2010). First, the recordings were transcribed verbatim, a final transcribed version was obtained and researchers read the whole data to familiarize themselves with the data before coding it. Then, the data set was coded manually by using both Nvivo coding, "a code which refers to a word or short phrase from the actual language found in the qualitative data record" (Saldaña, 2009, p.74) and descriptive coding which means using a word or short phrase developed by the researcher. Codes such as equipment, sports culture, 
Table 1: Participant and Demographics

\begin{tabular}{|c|c|c|}
\hline Job & Institution & Experience \\
\hline Ac1. Academician (Asst. Prof.) & University & 5 \\
\hline Ac2. Academician (Lecturer) & University & 6 \\
\hline Ac3. Academician (Lecturer) & University & 5 \\
\hline Ac4. Academician (Asst. Prof.) & University & 5 \\
\hline Ac5. Academician (Instructor) & University & 24 \\
\hline C1. Coach & Public School & 1 \\
\hline C2. Coach & $\begin{array}{l}\text { Provincial directorate } \\
\text { of sports }\end{array}$ & 14 \\
\hline C3. Coach & Public School & 10 \\
\hline C4. Coach & $\begin{array}{l}\text { Provincial directorate } \\
\text { of sports }\end{array}$ & 6 \\
\hline C5. Coach & $\begin{array}{l}\text { Provincial directorate } \\
\text { of sports }\end{array}$ & 34 \\
\hline C6. Coach & $\begin{array}{l}\text { Provincial directorate } \\
\text { of sports }\end{array}$ & 1 \\
\hline C7. Coach & $\begin{array}{l}\text { Provincial directorate } \\
\text { of sports }\end{array}$ & 1 \\
\hline C8. Coach & $\begin{array}{l}\text { Provincial directorate } \\
\text { of sports }\end{array}$ & 11 \\
\hline T1. Teacher & Public School & 10 \\
\hline T2. Teacher & Public School & 7 \\
\hline T3. Teacher & Public School & 15 \\
\hline T4 Teacher & Public School & 10 \\
\hline T5. Teacher & Public School & 16 \\
\hline T6. Teacher & Public School & 15 \\
\hline T7. Teacher & Public School & 10 \\
\hline T8. Teacher & Public School & 14 \\
\hline T9. Teacher & Public School & 23 \\
\hline T10. Teacher & Public School & 4 \\
\hline T11 Teacher & Public School & 4 \\
\hline Ath1. National Athlete & - & - \\
\hline Ath2. National Athlete & - & - \\
\hline Ath3. National Athlete & - & - \\
\hline Ath4. National Athlete & - & - \\
\hline Ath5. National Athlete & - & - \\
\hline
\end{tabular}

exam-centered education, mindsets have emerged from this procedure. Later, emerging codes were revisited and patterns were created that led to the final themes. Two researchers independently analyzed the data set, developed separate themes, and later had a discussion that eventually led to a consensus on the themes.

We ensured that the procedures performed in the study did not harm any participant by following the ethical of guidelines set by Siirt University Ethics Committee. We were also guided by 1964 Helsinki ethical principles involving human subjects, a protocol that was initially developed for scholars of medical research.

\section{FINDINGS \\ Developing a sports culture: The need for facilities, equipment and attention}

The first theme emerged was based on this question: 'do you think that the physical education and sports culture subject in the national education program is sufficient for the formation of sports culture? Why?'.'Can we give a sportive perspective on the students in public schools?'.

Almost all the participants stated that physical education and sports (PES) course is not sufficient enough to develop and sustain a sports culture. Lack of facilities and low level of significance towards the course were cited by a great majority of participants (20 participants) as two primary reasons why the course fails to nurture a sports culture while an inhibiting administrative and education system were among other cited reasons. One participant cautions that regardless of the larger systems that mostly determine the day-to-day organization, regulation and the-way-job-is-done of the school, individual school itself, and the school structure and culture can make a huge difference in the role of PE. Participants also stated that in many cases these factors lead to variance in the role physical education and sports course plays at schools.

Many participants underscore the importance of equipment and facilities as stated by A2:'No, the reason is that the PES course is not given adequate hours... the course is not efficient because of insufficient playgrounds, equipment etc. school teams take trainings and participate in competitions without meeting their basic needs'. T1 also refers to infrastructure of schools: 'First of all, time for physical education subject is inadequate, the curriculum is not realistic and the physical conditions for the subject are insufficient'. One of the most interesting finding was participants' references to teachers' routines of taking the attendance and then dismissing the class by telling students that they are free to do whatever they want. The remark by Ath 2 demonstrate this issue: 'I do not find effective enough, because the national education program fails to teach children the importance of the physical education subject. At my time, in physical education classes, we were freed after entering the classroom and taking the attendance. Discipline is a must...' Ath4 echoes T1: 'Personally I do not find them sufficient. The reason is that I see that the students are not encouraged to the sports in physical education courses. In the course the attendance was taken and we were then free. It was like an unnecessary course. I think that teachers should encourage students to participate in sports education and to get to know sportive culture.

The number of contact hours is also viewed as an issue as in this example: 'Students have 45 hours of subjects per week and 
only 2 hours for physical education. This is not enough. In some vocational high schools, it is even elective which summarizes the whole situation' (T5). Replacement of PSE courses with other courses as stated by Ath5 in these following sentences: ' $\mathrm{No}$, I do not find enough. There are no sports facilities in schools. Especially in the primary schools, other basic courses are held instead of physical education subject' seems to exacerbate the issue.

Several reasons are cited for why other courses are preferred over PES and the main one reflects the "teach to the test" mindset because school administrators opt for courses that students will be tested on in the standardized national tests over PES, a course from which students are not tested. Some administrators are even reported to blame PES a culprit for low academic achievement: '...because school administrators see the other subjects and national exams as more important for academic success. They even think that physical education course hinders students' success' (C2).

Some go beyond the school-level factors and point out the larger social and educational system by pointing out that '...in order for this culture to be formed, the system should be organized" (T7). C7 more specifically refers to the societal habits that restrict the development of a strong and sustainable sports culture: "I believe that the system has made society a sitting community. An athlete will not come out of a society that faces an examination every four years.

Teachers do not go unnoticed when it comes to their role in the failure to help students develop connections with sports and making it an essential part of their life. For example, AC2 calls attention to teachers' pedagogy and skills: 'We are inadequate in giving sportive perspective to the students. Are physical education teachers qualified? Is their training enough to shape these fresh brains and physics? Do they have the field information?. C5 joins this contention with a reflection: '... Because we do not have enough knowledge, skills and experience.... Parents' pressure and their continuous orientations towards central exams further contribute to the complex and multi-faceted nature of the issue: '...because of the family pressure, the students are more likely to focus on exams and stay away from sports' (T2). It, then, follows that the emphasis on exams is not only caused by the presence of central exams but also by the importance parents attach to these exams. It could also be argued that, at times, parents could act as barriers by discouraging their children from taking up sports activities.

\section{Sportive achievement as a grading input into the national standardized test}

This theme emerged based on responses to these following questions: 'The Ministry of National Education is preparing to accept sportive achievement as criteria in national exams such as TEOG, YGS. How do you evaluate this situation? Would this contribute to the education system?'.
All participants without any exception responded positively to this change. Many participants identify this policy as revolutionary and emphasize such a policy's contribution to nurturing successful athletes, thereby, increasing country's sportive success in national and international competitions as indicated in these quotes: 'This decision of the Ministry will change the viewpoints of the students as well as theirfamilies. We can discover more successful athletes in our country at a young age' (Ac3), 'I think it will contribute to the country. Because in our country, exams are prioritized over all other things. It is believed that the success of the students will decrease by doing sports'(T4), '... a late but thoughtful decision... It should be applied without losing time. Because of the exams the children are being kept away from sports by the parents. With this decision, at least the parents will guide and allow the successful children to the sports' (T9), and 'This is a good thing because it opens the way for those who have not succeeded in the classroom and succeeded in the sportive field. It will bring national success in terms of sports. As the number of people doing sports in the country increases, sport culture will be seen in the family' (Ath2).

However, some believe that other steps and initiatives (assigning good sports managers and coaches, opening and/or renovating facilities and supporting schools with equipment) must accompany such a policy: 'I believe that the contribution will be very positive. If the opportunities presented to the athlete and the managers are increased and if their basic needs are met it will be beneficial'(Ac2), 'I find it positive. It will enable the parents to see sportive activities positively. It must be supported with facilities and equipment; it may be insufficient by itself' (C5).

\section{Stagnation, inhibitors and moving forward}

Several factors, ranging from education ystem, mindsets to teachers, were cited by participants as culprits for the seemingly existent indifference for physical education courses.

\section{Broad pre-service education, facilities/equipment, absence of coaches, mindsets}

Participants first stressed the need for establishment of higher education institutions that are specialized on sport sciences. Such suggestions are more crystalized through statements of (Ac1) 'I think sports universities need to be established. I think that there will be a better education in the field with the help of the academicians who have good academic and sports curriculum vitae'.

Increasing the number of hours is followed by equipment and facilities as stated T4: 'First of all, it is necessary to increase the number of hours of Physical Education subject in schools. Then, there must be the materials (gym, etc.) for the physical education subject' and by T9: 'The biggest obstacle is the problem of facilities and sports fields. It is obvious that there is great difficulty in terms of material, especially at the primary and secondary schools. 
Recruitment of graduates of coaching majors in addition to graduates of physical education majors is suggested as another strategy to increase both specialization and timely and effective guidance of students towards sports branches based on their abilities. As seen in these direct quotes by Ac2: 'First, coaching graduates can be employed. Adequate instructor and appropriate facility must be provided. Weekend courses and materials may be provided to the students', people who are actively involved and have first-hand experience with these PE courses tend to focus on universities, equipment/facilities, on the increase in the number of courses and on having weekend classes as potential strategies. Moreover, a great number of them believe that employing sports coaches in collaboration with teachers will be very helpful in terms of better scanning of talents and of providing more fine-tuned guidance. The following quotes succinctly exemplify these arguments. 'There is much work for physical education teachers. I believe that the sports teachers should detect the qualifications of the students in the very beginning of the primary school and should direct them to the branches" (C4). "There should be special trainers in the main sports as well as routine physical education subjects. Coaching graduate students should be employed. Gymnasiums should be established in a school and it should be turned into campus system' (Ac5).

School administrators and their view of PE classes, overemphasis on academic competition with a unique focus on exams are among the other cited obstacles beyond effectiveness of these classes. Through these statements: 'First of all, the administration which prevents the socialization of children are the obstacles'(C2), '...because school administrators do not have a sports background, they have no respect for these teachers and subject...The fact that the managers do not see or respect this subject negatively affects the physical education teachers (Ac2), '...subjects such as mathematics, etc. are always more important. Unfortunately, according to some administrators, school and life consist of these lessons. (T6), 'Unfortunately, some of administrators are big obstacles" (C4), and '...unfortunately, sportive events are always on the second and third plan in our country. Sports are perceived as leisure time activity..."'(Ac3), 'As can be seen from the extra courses, these kinds of subjects are given much more importance. Many schools do not allow the opening of physical education courses. ... the school, the family and the overloading of the lesson. The fact that the students are in a constant competition prevents sportive activities' (T4), the participants underscore the importance of assumptions and norms towards PE courses.

The mismatch between sports clubs outside the schools and public schools is also emphasized. Almost all participants (26 out of 29) made references to the incompatibility between public schools and sports clubs. More clearly, it seems that these two entities work in contrast with each other leading to a stalemate in which students' active participation in sports club is perceived as a reason for low academic achievement. Put differently, while both PE course and sports clubs can co-exist and feed one another, the almost shared mindset in schools is that the activities of sports clubs delay and even obstruct students' academic performance and students almost always face a dilemma: focusing on academic work or engage in sports activities. These dilemmas and the lack of alignment are made explicit in these following statements: '...I think the student is in a dilemma. I do not think that the clubs and schools have good communication... (Ac2)', '...unfortunately, they look at each other as enemies. The reason for the failure of the child's school is entirely related to the workings of sports clubs. As a result, the student is constantly in a state of controversy, which weakens the athlete (Ac3), 'Unfortunately, there is no harmony. It is observed that the academic performance of the athletes who are active in the club is low' (T4), '...The clubs are trying to get the student away from the school. The student is also experiencing a dilemma. Clubs are blaming the schools and vice versa' (T7).

Participants also discussed the resulting status of Turkey's ranking in international sports tournaments by drawing on all the preceding factors. They discussed the country's international achievement with specific references to sports policies. Participants such as C3 called for a concerted effort between various governmental institutions: 'I see our sportive successes very bad for our country's population. Urgently, schools and sports managements should co-operate, coaching system should be brought and required equipment should be provided' while T8 highlighted the problems in education: 'There is no physical education subject in primary schools. National exam success in middle school and 1-hour lesson time in high school (vocational schools) adversely affect'. The sports policies that rely on borrowing foreign athletes and giving them citizenship are also heavily criticized: '...They go to Kenya, Ethiopia to pick up athletes and race on behalf of the country. If the money given to them is given to a local athlete, very talented athletes from the Eastern Anatolia Region or another region will emerge. If the background is strengthened with the support of the state in those regions, there is no need for foreign sportsmen' (T11). Interestingly one participant draws a correlation between sports policies and degenerative diseases such as obesity: '... Sports education policies should be seriously considered and steps must be taken. Societies without sports culture deal with diseases, obesity etc. and this is costly to the country' (Ac2).

\section{Discussion and Conclusion}

This study that focuses on a multiple stakeholders' perspective and experiences with PE classes reveal four main points of discussion and areas of improvement in regard with $\mathrm{PE}$ course at K-12 education: denomination of PE mostly due to high-stake testing, the lack of facilities and equipment, the felt need to support PE teachers with coaches and special trainers. 
It is quite interesting and disheartening to observe that a class that is so much favored and loved by students and adults including educators (Balga, Antala, \& Argajová, 2019; Çelik, Koçkaya \& Parlar, 2018; Demir, Cicioğlu, İlhan, \& Arslan, 2017; Graham, 2008; Mohammed \& Mohammad, 2012; Pehlivan, Dönmez \& Yaşat, 2005; Sağın and Karabulut (2019; Tutal, 2014) is largely marginalized and undermined. As articulated by participants in this study, it appears that much talk by stakeholders at schools on this course does not go beyond rhetoric and what happens in practice is a complete opposite. As a matter of fact, participants' quotes highlight the use of particularly four discourses articulated by Jung, Pope, and Kirk (2016): sports, health, citizenship, olympic. Looking through Schlecty's (2015) preachment, practice, pretests framework, our results point out much preachment, very strong pretests and minimal practice because in narrative neither administrators nor teachers question and deny the significance of the physical education course. This finding is supported by previous studies (e.g., Varol, 2014; Zeng \& Wang, 2015) that found that school principals' self-reported perceptions are very positive. It is understandable that selfreports confirm the preachments. However, perceptions and experiences of teachers, coaches and athletes expose deeply held beliefs and assumptions regarding PE course's role in developing a whole-child. Some of these shared beliefs become more evident in actual instances of replacing the course with other tested courses (e.g., maths, science). The marginalization of $\mathrm{PE}$ courses in this study context both corroborates and contradicts with Penney's (2017) contention that "physical education curriculum, pedagogy and assessment are discursively constrained" (p.571). In our case, too, PE is, in discourse, recognized, its benefits are acknowledged, and are highly spoken of. However, exchange of PE course with other courses seems to be prevalent as indicated by students in the study conducted by Mohammed and Mohammad (2012) and Pehlivan, Dönmez and Yaşat (2005). The fact that what happens in practice is not used as an opportunity to unearth and question these underlying assumptions imply that people who make such decisions, which degrade physical education course and deprive students off an experience they highly need and enjoy, are content with the current status. It seems that pretenses regarding this course continuously influence practice while preachments remain intact, a finding corroborated by prior research (Pehlivan, Dönmez \& Yaşat, 2005; Varol, 2014). All these highlight the fact that the issue is one of a culture and mindsets. For such a culture to change, a strong willingness and metanoia (mindsets) followed by genuine action (actionsets) is needed to bring back the value and justice to the PE course.

To develop and sustain a new culture that rightfully appreciate PE course, the factors the sustain the current mental models need to be scrutinized. Exchanging PE with other basic courses bring forth the consequences of the phenomenon of 'teach-to-the test'. There are not formal accountability schemes in the context of this study, however, there is a prevalent 'teachto-the test' approach towards education due to a high-stakes testing at the end of both middle and high school. The existence of such high-stake tests appears to have created prioritized courses in education and turned schools into communities of classes where all classes are equal but some are more equal. The "assessed/non-assessed knowledge, skills and understandings" (Penney, 2017, p. 574) as a boundary in PE seems to be evident in our case, too. The sense of urgency created by the tests that focus more on numeracy and literacy creates a neverending vicious circle impacting everyday PE pedagogical practices and reconstructing stakeholders' deeply held beliefs in PE courses. These tests evidently lead to marginalization of curriculum (Penney, 2017, p. 576) and our study clearly shows the marginalization of PE curriculum. We think that the problem does not stem from that "adverse practice shortcomings" endanger policy narrative (Hardman, 2008). The problem, rather, it is mostly generated by wider education policy context that direct individuals' perspectives and practices. In other words, while our study confirms "the gap between official policy and regulations and actual practice" (Hardman, 2008, p.8), it's the presence of another policy (highstake assessments at primary and secondary school level) that meddles with the practices of PE and minimizes students' engagement with physical activity. We can then conclude that short-comings in a concurrently present educational policy and practice (high-stake tests) have some spilling effects on the practice of another educational endeavor (physical activity). The context of PE described in this paper is yet another example in which PE is seen as a "soft policy" (Kennedy, Chan, \& Fok, 2011) exemplified by "the apparent lack of involvement of education authorities in its development and implementation despite the fact that it is a school-based policy" (Stylianou, Hogan \& Enright, 2019, p. 193).

Our study has also shown that the culture of the schools have strong influence on behavior and attitudes towards PE course and that the lack of facilities, equipment, and fewer number of PE classes prevent students from fully benefiting from PE course. This is a finding that is corroborated by Mohammed and Mohammad (2012) who found out that limited number of PE class sessions prevents most students from making most out of these classes. We believe the issue is more complex. Does lack of infrastructure breed the culture or the culture restrain the infrastructure? It would make sense to postulate that policy-makers and administrators fail to act in terms of facilities, equipment, number of PE classes because they do not view PE as an integral component and facilitator of academic achievement. So, the issue is of a consciousness / awareness one, too. Thus, it could be wisely assumed that increased knowledge and consciousness at policy and school 
level could create the capacity to unearth and question the assumptions towards $\mathrm{PE}$ which, in turn, could lead to a better provision of PE courses in terms of quantity and quality.

Another issue apart from attitudes and structural issues with provision of $\mathrm{PE}$ is about the quality of classes that, as suggested by participants in this study, could be fostered through the recruitment of coaches to collaborate with teachers. The belief is that PE should not only be viewed as a course for leisure activity but it should also be used as a tool to increase the future success in athletic sports by selecting students with the potential and training them in a more systematic way. Turkey currently has a lot of foreign athletes who are naturalized as Turkish citizens to represent the country in international games. Such an approach includes issues of sustainability and fairness. PE courses are not to be viewed only as play opportunities for students but as venues of students' selection for competitive sports. In that sense, PE courses offer strategic opportunities for countries to determine the individuals on whom to invest. They could and should be sustainably used to screen, select and train national athletes that could represent the country in competitive sports. The problem identified in this study confirms "the absence of a systematic or even coherent approach to elite youth development" (Kristiansen \& Houlihan, 2017, p. 463). Therefore, coaches who can identify the talent and who can liaison between schools and clubs need to be recruited. It is also worth listening to Smith's (2015) warning of "privatization aspects of PE" (p.886). When employing coaches, the vested interests of these private coaches must be carefully considered. That is because some coaches might be more concerned about commercial aspect of coaching and might widen the existing social inequalities among students by making coaching more accessible to students holding higher strata of socio-economic development.

\section{Implications}

Despite a plethora of benefits PE course could bring to students, it is constrained by various factors most of which are external to schools and the most potent of which is "teach-to-thetest", a relatively new mandated approach to instruction and education. In the context where the data in this study was drawn, there are no accountability measures but high-stake standardized tests have been redirecting education resources to preparation of these tests that students are exposed to at the completion of middle and secondary school. In such a context, PE courses can be effectively used as stress-reduction, physical and psychological health-maximizing sites. They could also be organized in ways that could transform students' self-perceptions and assist in developing healthy routines. The current problems facing PE courses are more cultural than structural (the number of PE courses, teachers to facilitate, and students to benefit). Thus, the problem calls for a change in mindsets first followed by changes in action-sets. It is a truism that PE cannot find its way into standardized test in the short run, a fact that is already embraced by the stakeholders. Then, the first action to be able restore the value of $\mathrm{PE}$ is a policy-level action: turning PE course policy into a hard policy and using the terms of Valverde, Bianchi, Wolfe, Schmidt and Houang's (2002) making it a course that is truly implemented rather than being only intended. Then, comes equipping schools with tools and the recruitment of coaches at schools to help select and further train potential elite athletes. Development of a better communication between sports clubs and public schools so the activities in both institutions could support and build on one another will also surely contribute to an enhanced role of $\mathrm{PE}$. We finally note that the consideration of engagement in sports activities and sportive achievement as a grading input in the national standardized tests is viewed and could be quite an innovative policy driver considering its potential to bolster the participation of youth in sports.

\section{Limitations}

The study has followed a qualitative research design; therefore, it is explorative in nature and has not intended nor has engaged in drawing general trends and/or in establishing statistical correlation and causality. Accordingly, it represents experiences of only a handful of relevant key people living in a certain geographical region. The study could also have explored changes in experiences of relevant people over time by employing longitudinal and ethnographic research designs that could have allowed the use of observation and have enabled the researchers to draw a more complete and detailed picture of the phenomenon.

\section{References}

Balga, T., Antala, B., \& Argajová, J. (2019). Attitudes of elementary school pupils towards physical education and their differentiation from the point of view of age, sporting level and gender. Journal of Physical Education and Sport, 19(1), 552-559.

Beni, S., Chróinín, D.N., \& Fletcher, T. (2019). A focus on the how of meaningful physical education in primary schools. Sport, Education and Society, 24(6), 624-637. DOI: 10.1080/13573322.2019.1612349.

Bozoglu, O., \& Göktürk, S. (2016). What's going on in physical education classes in Turkey?: An insight into student attitude towards physical education, curricular issues and school conditions. Journal of Education and Practice, 7(33), 156-165.

Çelik, A., Koçkaya, E., \& Parlar, F. (2018). Orta öğretim düzeyi öğrencilerin beden eğitimi ve spor dersi tutumları: Trabzon ili örneği. Beden Eğitimi ve Spor Bilimleri Dergisi, 20(4), 34-42.

Chomitz, V. R., Slining, M. M., McGowan, R. J., Mitchell, S. E., Dawson, G. F., \& Hacker, K. A. (2009). Is there a relationship between physical fitness and academic achievement? Positive 
results from public school children in the northeastern United States. Journal of School Health, 79(1), 30-37.

Demir, G. T., Cicioğlu, H. İ., İlhan, E. L., \& Arslan, Ö. (2017). Sınıf öğretmeni adaylarının beden eğitimi dersine yönelik tutumları. Uluslararası Spor, Egzersiz ve Antrenman Bilimi Dergisi, 3(4), 120-128.

Demirhan, G., Bulca, Y., Saçlı, F., \& Kangalgil, M. (2014). Beden eğitimi öğretmenlerinin uygulamada karşılaştıkları sorunlar ve çözüm önerileri. Hacettepe Üniversitesi Ĕ̆itim Fakültesi Dergisi, 29(29-2), 57-68.

Engstrom, D. (1999). Correlations between teacher behaviors and student evaluations in college level physical education activity courses. Physical Educator, 56(2), 105-113.

Gordon, B., Dyson, B., Cowan, J., McKenzie, A., \& Shulruf, B. (2016). Teachers' perceptions of physical education in Aotearoa/New Zealand primary schools. New Zealand Journal of Educational Studies, 51(1), 99-111.

Graham, G. (2008). Children's and adults' perceptions of elementary school physical education. Elementary School Journal, 108(3), 241-249. DOI: 10.1086/529106.

Haible, S., Volk, C., Demetriou, Y., Höner, O., Thiel, A., Trautwein, U., \& Sudeck, G. (2019). Promotion of physical activity-related health competence in physical education: study protocol for the GEKOS cluster randomized controlled trial. BMC Public Health, DOI: 10.1186/s12889-019-6686-4.

Hardman, K. (2008). Physical education in schools: A Global Perspective. Kinesiology: International Journal of Fundamental and Applied Kinesiology, 40(1), 5-28.

Hayes, S., Capel, S., Katene, W., \& Cook, P. (2008). An examination of knowledge prioritisation in secondary physical education teacher education courses. Teaching and Teacher Education, 24(2), 330-342.

Jung, H., Pope, S., \& Kirk, D. (2016) Policy for physical education and school sport in England, 2003-2010: Vested interests and dominant discourses. Physical Education and Sport Pedagogy, 21(5), 501-516, DOI: 10.1080/17408989.2015.1050661.

Kennedy, K. J., Chan, J. K., \& Fok, P. K. (2011). Holding policymakers to account: exploring 'soft' and 'hard' policy and the implications for curriculum reform. London Review of Education, 9(1), 41-54.

Kim, M., Cardinal, B. J., \& Cardinal, M. K. (2015). Diversifying physical activity course curricula to meet institutional expectations and satisfy student needs in higher education: An introductory framework. The Journal of Physical Education, Recreation and Dance, 86(9), 5-8.

Kirkham-King, M., Brusseau, T. A., Hannon, J. C., Castelli, D. M., Hilton, K., \& Burns, R. D. (2017). Elementary physical education: a focus on fitness activities and smaller class sizes are associated with higher levels of physical activity. Preventive Medicine Reports, 8, 135-139.

Kohl III, H. W., \& Cook, H. D. (2013). Educating the student body: Taking physical activity and physical education to school. Washington: National Academies Press.

Kristiansen, E., \& Houlihan, B. (2017). Developing young athletes: The role of private sport schools in the Norwegian sport system. International Review for the Sociology of Sport, 52(4), 447-469.

Lund, S. (2014). Regulation and deregulation in education policy: new reforms and school sports in Swedish upper secondary education. Sport, Education and Society, 19(3), 241-257, DOI: $10.1080 / 13573322.2012 .664127$.

Mamak, H. (2012). İlköğretim okullarında beden eğitimi ve spor derslerinin amaçlarına ulaşma düzeyini etkileyen faktörler. Selçuk Üniversitesi Beden Ĕ̆itimi ve Spor Bilim Dergisi, 14(1), 109-115.

Marinsek, M., \& Kovac, M. (2018). Beliefs of Slovenian early childhood educators regarding the implementation of physical education. European Physical Education Review, DOI: https:// doi.org/10.1177/1356336X18761538.

McKenzie, T. L., \& Lounsbery, M. A. (2009). School physical education: The pill not taken. American Journal of Lifestyle Medicine, 3(3), 219-225.

Mercier, K., Donovan, C., Gibbone, A., \& Rozga, K. (2017). Three-year study of students' attitudes toward physical education: Grades 4-8. Research Quarterly for Exercise and Sport, 88(3), 307-315. DOI: 10.1080/02701367.2017.1339862.

Miles, M. B. \& Huberman, A. M. (1994). Qualitative data analysis. London: Sage Publication.

Ministry of National Education [MoNE] (2018a). Beden eğitimi ve oyun dersiöğretim programi (İlkokul 1, 2, 3 ve 4. sinıflar). Retrieved from http://mufredat.meb.gov.tr/Dosyalar/2018102311522378106-Beden\%20E\%C4\%9Ftimi\%20ve\%200yun\%202018-124\%20 Eki\%20\%C3\%96P.pdf.pdf.

Ministry of National Education [MoNE] (2018b). Beden eğitimi ve oyun dersi öğretim programi (İlkokul 1, 2, 3 ve 4. sinıflar). Retrieved from http://mufredat.meb.gov.tr/Dosyalar/2018120201950145BEDEN\%20EGITIMI\%20VE\%20SPOR\%20OGRETIM\%20 PROGRAM\%202018.pdf.

Mohammed, H. R. A., \& Mohammad, M. A. (2012). Students' opinions and attitudes towards physical education classes in Kuwait public schools. College Student Journal, 46(3), 550-566.

Morrow Jr, J. R., Martin, S. B., Welk, G. J., Zhu, W., \& Meredith, M. D. (2010). Overview of the Texas youth fitness study. Research Quarterly for Exercise and Sport, 81(3), S1-S5.

Nisskaya, A. K. (2018). What modern parents think about preschool education: What makes a preschool attractive? Russian Education \& Society, 60(7), 601-622. DOI: 10.1080/10609393.2018.1527165.

Oh, J., \& Graber, K. C. (2019). Physical education teacher education leaders' perceptions on a national curriculum in physical education. Research Quarterly for Exercise and Sport, 90(3), 362-376. DOI: 10.1080/02701367.2019.1603988.

Osborne, R., Belmont, R. S., Peixoto, R. P., Azevedo, I. O. S. D., \& Carvalho, A. F. P. D. (2016). Obstacles for physical education teachers in public schools: An unsustainable situation. Motriz: Revista de Educação Física, 22, 0310-0318.

Pehlivan, Z., Dönmez, B., \& Yaşat, H. (2005). Sınıf öğretmenlerinin beden eğitimi dersine yönelik görüşleri. Gazi Beden Eğitimi ve Spor Bilimleri Dergisi, 10(3), 51-62.

Penney, D. (2017). Big policies and a small world: An analysis of policy problems and solutions in physical education. Sport, Education and Society, 22(5), 569-585, DOI:10.1080/1357332 2.2016.1242066.

Penney, D. (2017). Big policies and a small world: an analysis of policy problems and solutions in physical education. Sport, Education and Society, 22(5), 569-585.

Phillips, S., \& Silverman, S. (2015). Upper elementary school student attitudes toward physical education. Journal of Teaching in 
Physical Education, 34(3). 461-473. DOI: 10.1123/itpe.2014$\underline{0022 .}$

Plano Clark, V. L., \& Creswell, J. W. (2014). Understanding research: A Consumer's guide. Boston: Pearson.

Sağın, A. E., \& Karabulut, Ö. (2019). Beden eğitimi ve spor dersine yönelik ortaokul öğrencilerinin değer düzeylerinin incelenmesi: Bağcılar ilçesi örneği. Uluslararası Dağcılık ve Tirmanış Dergisi, 2(2), 27-34.

Saldaña, J. (2021). The coding manual for qualitative researchers. Sage.

Sallis, J. F., McKenzie, T. L., Beets, M. W. \& Beighle A. (2012). Physical education's role in public health. Research Quarterly for Exercise and Sport, 83(2), 125-135, DOI: 10.1080/ 02701367.2012.10599842.

Schlecty, P. (2015). Understanding the normative system. In Grogan M. (Ed.). The Jossey-Bass reader on educational leadership (pp.221-237). San Francisco: Jossey-Bass.

Simmons, J., \& MacLean, J. (2018). Physical education teachers' perceptions of factors that inhibit and facilitate the enactment of curriculum change in a high-stakes exam climate. Sport, Education and Society, 23(2), 186-202.

Smith, A. (2015). Primary school physical education and sports coaches: Evidence from a study of school sport partnerships in North-West England. Sport, Education and Society, 20(7), 872-888. DOI: 10.1080/13573322.2013.847412

Stylianou, M., Hogan, A., \& Enright, E. (2019). Youth sport policy: The enactment and possibilities of 'soft policy' in schools. Sport, Education and Society, 24(2), 182-194, DOI: 10.1080/13573322.2017.1339685.

Talim Terbiye Kurulu Başkanlığ (2018). Haftalık ders çizelgeleri. Retrieved from https://ttkb.meb.gov.tr/www/haftalik-derscizelgeleri/kategori/7.

Tercedor, P., Villa-González, E., Ávila-García, M., Díaz-Piedra, C., Martínez-Baena, A., Soriano-Maldonado, A., ... \& HuertasDelgado, F. J. (2017). A school-based physical activity promotion intervention in children: Rationale and study protocol for the PREVIENE Project. BMC Public Health, 17(1), 1-10.

Tutal, V. (2014). Okul yöneticilerinin beden eğitimi dersine ilişkin tutumlarının bazı değişkenlere göre incelenmesi. Retrieved from http://openaccess.inonu.edu.tr:8080/xmlui/ bitstream/handle/11616/5148/Tez\%20Dosyas\%C4\%B1.pdf? sequence $=1$ \&isAllowed $=y$.

U.S. Department of Health and Human Services (2010). Healthy People 2010: Understanding and Improving Health. Retrieved from https://www.healthypeople.gov/2010/document/pdf/ uih/2010uih.pdf.

Valverde, G. A., Bianchi, L. J., Wolfe, R. G., Schmidt, W. H., \& Houang, R. T. (2002). According to the book: Using TIMSS to investigate the translation of policy into practice through the world of textbooks. Springer Science \& Business Media.

Zeng, H. Z., \& Wang, X. (2015). Exploring principals' physical education perceptions and views from elementary and middle schools of Shanghai. World Journal of Education, 5(6), 37-49. 